\title{
The Diver's New Papers: Wealth, People, and Property in a Persian Gulf Bazaar
}

\author{
Fahad Ahmad Bishara \\ University of Virginia, Charlottesville, Virginia, USA \\ bishara@virginia.edu
}

\begin{abstract}
This article explores the contours of debt and labor in the early twentieth-century Persian Gulf pearl dive. It examines the barwa, a declaration exchanged by nakhodas (dhow captains) about the amounts that divers owed and the terms by which they might be hired out. By looking both through and at the barwa, we find a window into the Indian Ocean maritime bazaar, and into the artifacts through which mobile and itinerant laborers were bound to the dhow and its captain. Maritime actors used these papers to navigate the boundary between person and property, and between free and unfree, all within a changing commercial and legal world.
\end{abstract}

\section{Keywords}

Persian Gulf - Indian Ocean - pearl diving - slaver - barwa - personhood credit - dhow

\section{Introduction}

On the morning of March 21, 1928, an African by the name of Sa'id bin 'Ali walked into a government office on the Persian Gulf island of Bahrain and presented Charles Belgrave, the recently-appointed British Adviser, with a written petition. In it, he asserted that he had received a manumission certificate from the British Political Agency but that after searching for employment on one of the many pearling dhows on the island he found that "none of the 
nakhodas ${ }^{1}$ [dhow captains] agreed to employ [him]." He then proceeded to ask Belgrave to give him a barwa - a certificate attesting to his ability to take on loans - "so that [he] could work with one of the nakhodas, for if there was not one in [his] hands they would not accept [him]."2 Sa'id's case was common: around the Persian Gulf, there were hundreds like him over the course of the 1920s-enslaved people who approached the British Political Agency asking for both a manumission certificate and a barwa that would allow them to participate in the summer pearl dive. ${ }^{3}$

The scene might seem familiar. Historians have long identified an unsavory relationship between debt and slavery-specifically, how different forms of debt had led to enslavement or sale of debtors by their creditors. For some historians of Africa, perhaps the most recognizable manifestation of this relationship was the phenomenon of pawnship, by which individuals were held as collateral for loans incurred, throughout the duration of and well after the Atlantic slave trade. ${ }^{4}$ Others have pointed to the existence of debt bondage alongside slavery in different parts of the world, particularly in the context of nineteenth-century commercialization and the heightened demand for labor it brought with it. ${ }^{5}$ Though debt bondage did not necessarily lead to slavery in all parts of the world, the two were close enough in the minds of scholars and observers alike as to create a disagreeable association between finance, capitalism, and labor.

But Sa'id was not complaining about debt bondage; rather, he was asking for the right to take on debt- to enter himself into a nakhoda's ledger book. This, too, is not altogether unfamiliar: historians have acknowledged that not all forms of finance were pernicious - that credit, rather than debt, might be

1 In the Arabic, the term is nawkhidha, and in the Persian, it is nakhuda. Nakhoda continues to be used by historians, and it is the spelling I retain in this article, for purposes of identification.

2 C.D. Belgrave to Political Agent (March 28, 1928) India Office Records (hereafter, IOR) $\mathrm{R} / 15 / 2 / 1905$.

3 See the petitions in IOR $\mathrm{R} / 15 / 2 / 1905$ and $\mathrm{R} / 15 / 1 / 209$.

4 See also T. Falola and P. Lovejoy, ed., Pawnship in Africa: Debt Bondage in Historical Perspective (Boulder: Westview Press, 1994); P. Lovejoy and D. Richardson, "The Business of Slaving: Pawnship in Western Africa, c. 16oo-1810." Journal of African History 42/1 (2001): 67-89. For a masterful treatment of debt and slavery in the Atlantic, see J.C. Miller, Way of Death:Merchant Capitalism and the Angolan Slave Trade, 1730-1830 (Madison: University of Wisconsin Press, 1988).

5 G. Campbell and A. Stanziani, ed., Bonded Labour and Debt in the Indian Ocean World (London: Pickering \& Chatto, 2013); G. Campbell and A. Stanziani, Debt and Slavery in the Mediterranean and Atlantic Worlds (London: Pickering \& Chatto, 2013). 
just as usefully understood as an integral component of economic life among laborers both free and unfree. Historians of East Africa in particular have highlighted the ways in which enslaved people sought to participate in the marketplace by taking on loans, investing in themselves and in others, and developing independent forms of wealth. ${ }^{6}$ Although the literature on credit, slavery, and economic life is not nearly as developed as that on its cousin, debt, the insights this scholarship has yielded so far have been rich enough to merit their extension into places where these debates have been less developedplaces like the Persian Gulf, where mariners also took on loans and often blurred the fine line between freedom and enslavement. ${ }^{7}$

To make sense of the exchange that took place between Sa'id bin 'Ali and Belgrave in 1928, we need to step back and survey the scene more broadly- to understand the contours of credit, debt, and economic life for the always-free and recently-manumitted alike. At the heart of it all lay the barwa-a written declaration of debt owed by the mariner to his nakhoda that was generated as a matter of course in the maritime economy during the nineteenth and earlytwentieth centuries. The barwa was small and inconspicuous, often no larger than a business card, but is critically important to understanding the changing maritime economy of the Gulf. By looking through the barwa and into the maritime economy of the Persian Gulf, we can establish a material link between mariners, the debts they took on, and the accounts they were entered into. But just as importantly, by looking at the barwa, we are able to see the artifacts through which a changing body of mobile and itinerant laborers were bound to the dhow and its captain, the anxieties these documents caused, and the legal transformations they set in motion. Despite its mundanity, or perhaps precisely because of it, the barwa allows the historian an entry point into the arena of economic life at a time of at a time of enormous political, economic, and juridical change.

6 J. Glassman, Feasts and Riot: Revelry, Rebellion, and Popular Consciousness on the Swahili Coast, 1856-1888 (London: James Currey, 1995); J. Prestholdt, Domesticating the World: East African Consumerism and the Genealogies of Globalization (Berkeley: University of California Press, 2008); E. McMahon, Slavery and Emancipation in Islamic East Africa: From Honor to Respectability (Cambridge: Cambridge University Press, 2013); T.F. McDow, Buying Time: Debt and Mobility in the Western Indian Ocean (Athens OH: Ohio University Press, 2018).

7 The literature on slavery in the Gulf has been growing, but remains very limited. Notable examples of recent contributions include M. Hopper, Slaves of One Master: Globalization and Slavery in Arabia in the Age of Empire (New Haven: Yale University Press, 2015); B. Mirzai, A History of Slavery and Emancipation in Iran, 1800-1929 (Austin: University of Texas Press, 2017); J. Zdanowski, Speaking with Their Own Voices: The Stories of Slaves in the Persian Gulf in the 2oth Century (Cambridge, UK: Cambridge Scholars Press, 2014). 
To best comprehend the barwa, we have to set it against the backdrop of the maritime bazaar - a site of finance, of contracting, of wealth accumulation and conversion, and of capitalism more broadly. ${ }^{8}$ As a conceptual space, the bazaar allows us to anchor our analyses in the forms of paper that linked mariners to their nakhodas, dhows to shops, and credit forms to the commodity circulations they set in motion at a time of change in the markets for goods and labor. And as an arena of contending visions of the economic, the bazaar serves as a platform for reading the discourses that sought to frame the financial regimes of the maritime economy within broader ideas about freedom, slavery, and economic life.

Brought together, the barwa and the bazaar allow us to reconceive the maritime economy of the Persian Gulf during the nineteenth and twentieth centuries. In the bazaar, different actors sought to attach themselves to one another, building a form of wealth in people that allowed for the accumulation of (but sometimes conversion into) other forms of wealth. By following the barwa from the spaces in which it was generated and around the sites through which it traveled, we are able to see the forms of association that people forged through paper instruments, but also how those changing constellations of money, people, and goods opened the bazaar up as an arena of contestation over ideas of credit and debt-over the fine line between personhood and property, and persons as property, that shaped participation in the maritime economy. Looking through the barwa and at it, we see how different forms of wealth, in people and in property, circulated alongside one another in the maritime bazaars of the Persian Gulf, and how, at different junctures, they bled into one another.

"Everyone was in debt," wrote Alan Villiers, who traveled with a Kuwaiti dhow around the Indian Ocean in the late 193os and had occasion to observe

8 The standard reference in writings on the bazaar is C. Geertz's "The Bazaar Economy: Information and Search in Peasant Marketing." American Economic Review, 68/2 (1978): 28-32. Geertz's study gave rise to other studies in different settings. See also R.K. Ray, "Asian Capital in the Age of European Domination: The Rise of the Bazaar, 180o-1914." Modern Asian Studies, 29/3 (1995): 449-554; A. Keshavarzian, Bazaar and State in Iran: The Politics of the Tehran Marketplace (Cambridge: Cambridge University Press, 2007). For an understanding of the bazaar as a space of contracting and an arena of global capitalism, see F. Bishara and H. Wint, "Into the Bazaar: Indian Ocean Vernaculars in the Age of Global Capitalism." Journal of Global History 16/1 (2020): 44-64. 
the pearl dive; "the diver to the nakhoda, the nakhoda to the merchant who financed him, the merchant to some other merchant bigger than himself, the bigger merchant to the sheikh."9 Debt and credit were widespread: observers have described the ways in which merchants and nakhodas used advances to secure the labor of mariners. For pearl divers, these mostly came in the form of off-season loans, which served to support the divers and their families in the months leading up to the summer pearl dive. However, even those who had employment during the off-season - in many cases, divers would go and work on long- and short-distance trading dhows between September and May-still relied on regular advances from nakhodas..$^{10}$ Debt was thus an entrenched feature of the maritime economy writ large.

But rather than assume an enduring link between debt and the pearl dive, we might historicize it, and instead see its entrenchment in the twentieth-century Gulf maritime economy as an outcome of a nineteenth-century process by which the industry became more deeply integrated into Indian Ocean markets and the global economy. I am not suggesting that credit in the pearl dive was a nineteenth-century invention; what little information we have for earlier periods would immediately challenge that notion. Like virtually every other maritime enterprise around the world, actors in the pearl dive had long relied on loans and other advances, if not from nakhodas then directly from merchants or local political figures. ${ }^{11}$ What distinguished this period from what came before it, though, is the visibility of the strategies by which merchants and nakhodas made use of credit to stake out the boundaries of their enterprise. Through a combination of loans and barwas, these actors gave shape to the dhow as a maritime firm that bridged a changing body of laborers together with the organized "production" (insofar as one can call it that) of pearls. "The dhow" I refer to in this section heading, then, is a site of maritime labor contracting, rather than the vessel as such.

The background against which these processes unfolded is important. Though pearls had long found a market in India, recent scholarship has suggested that starting somewhere around the middle of the 19th century the market began to swell; by the last quarter of the century profits had increased tremendously,

9 A. Villiers, Sons of Sinbad (New York: Charles Scribner's Sons, 1969): 353.

10 See also Y. Al-Hijji, Kuwait and the Sea: A Brief Economic and Social History (London: Arabian Publishing, 2010): 26-36; F.A. Bishara, "A Sea of Debt: Histories of Commerce and Obligation in the Indian Ocean, 1850-1940." (Ph.D. Dissertation, Duke University, 2012): 79-92.

11 A useful discussion of this phenomenon in the eighteenth-century Gulf is found in W. Floor, The Persian Gulf: The Rise of Gulf Arabs, The Politics of Trade on the Persian Littoral, 1747-1792 (Washington, DC: Mage Publishers, 2007): 332-9. 
and the boom reached a crescendo in the first two decades or so of the twentieth century. This growth was in part due to political transformations that were taking place in the lower Gulf that brought some stability to the political geography of the region and reduced the likelihood of armed clashes at sea. More significant, though, was the growing demand for Gulf pearls among consumers in Europe and the United States, which allowed the merchants who financed the pearl dive to demand more for their catch in markets like Bombay; between 1873 and 1906, the price of pearls nearly doubled, and there is evidence that in the two decades before 1873 they experienced significant increases as well. ${ }^{12}$ The emergence of Bombay as a regional commercial center further infused the Gulf with merchants and capital to finance pearl exports, tightly binding the Gulf pearl banks to the markets of India. ${ }^{13}$

The commercialization of pearling was marked by the arrival of waves of Indian and Persian merchants who sought to establish a presence in the ports on the Arab littoral. Contemporary observers and historians alike have pointed out that during the 19th century, the port cities and marketplaces of the Persian Gulf hosted a diverse array of merchants. ${ }^{14}$ Virtually all of these belonged to much broader transregional firms: Arab pearl merchants had partners in major urban markets in Western India, principally Bombay. ${ }^{15}$ Alongside this network of Arab merchants was a community of Gujarati financiers who were highly active in the pearl industry from at least the mid-nineteenth century onward. ${ }^{16}$

12 See also Carter, Sea of Pearls: 141-81; Hopper, Slaves of One Master: 80-104; G.L. Durand, "Notes on the Pearl Fisheries of the Persian Gulf," Report on the Administration of the Persian Gulf: Political Residency and Muscat Political Agency for the Year 1877-78: 39.

13 N. Fuccaro, Histories of City and State in the Persian Gulf: Manama since 1800 (Cambridge: Cambridge University Press, 2009): 54.

14 See also J. Onley, "Transnational Merchant Families in the Nineteenth-Century Gulf." In Transnational Connections and the Arab Gulf, ed. M. Al-Rasheed (London: Routledge, 2004): 37-56; Fuccaro, Histories of City and State; F.A. Bishara, A Sea of Debt: Law and Economic Life in the Western Indian Ocean, 1780-1950 (Cambridge: Cambridge University Press, 2017).

15 Al-Shamlan listed the names of fifteen Arab pearl merchants from around the Persian Gulf who resided in Bombay during the early twentieth century, along with the names of seven Gulf Arab brokers; these, he noted, were only the most famous members of the Arab pearl trading community in the city. S. Al-Shamlan, Tärīkh Al-Ghawș 'ala al-Lu'lu'fi al-Khalïj al-'Arabī (Kuwait: Mațba'at Hukūmat Al-Kuwait, 1975) 2: 253-64.

16 An 1865 report suggested that "the great majority [of the mariners] are in the hands of agents of the Pearl merchants, whether Hindoo or other, who reside in the towns of the littoral. These agents make advances of money to the divers during the non-diving season, and when the spring comes on, the boats are supplied with so many days' dates, rice, and other provisions." "Report by Sir L. Pelly on the Pearl Fisheries of the Persian Gulf (1865)" in Royal Commission on Fugitive Slaves: Report of the Commissioners (London, 1876): 215. An 1877 British report on the Bahraini pearl diving industry highlighted the presence of 
These, historians have pointed out, were often not independent traders, but operated as members of firms with branches in all of the major port cities of the Western Indian Ocean, and some minor ones as well. ${ }^{17}$ Most did their business through local merchants, many of whom either financed a pearling dhow directly or sailed out to the pearl banks and purchased pearls from nakhodas and their crews.

As the value commanded by Gulf pearls rose along with the sheer number of pearls fished, the demand for labor-for divers, haulers, apprentices and the like- expanded as well. By the end of the nineteenth century, the Gulf emerged as the world's leading producer of pearls; the gross value of pearls exported from the region amounted to more than the combined pearls exports of all of the other pearl banks around the globe, and the pearl fisheries employed more mariners than any other pearl-producing region in the world..$^{18}$ According to one historian, this insatiable demand for labor led to substantial increases in the importation of slaves into the Gulf from East Africa and the Makran Coast of Persia and Baluchistan. ${ }^{19}$ The pearling boom also attracted free laborers, mostly from Persia, but also from the interior of the Arabian Peninsula, Oman, Yemen and as far as Somalia, who also joined the ranks of the mariners on board Gulf pearling dhows. Although some of these mariners took up residence in the Gulf, most maintained only a seasonal presence, coming in only to dive during the summer months. ${ }^{20}$ During the pearling season, towns comprised of make-shift huts emerged around the Bahraini capital of Manama; in 1923, the British Political Agent there reported that the town's population increased by $20,000-30,000$ during the summer pearling season. ${ }^{21}$

"no other than our friend the Indian Bunneah [Bania], whom we find equally at home here as in the wilds of the northern ranges beyond the Indus." Durand, "Notes on the Pearl Fisheries of the Persian Gulf": 27.

17 See also McDow, Buying Time; Bishara, A Sea of Debt; H. Wint, "Credible Relations: Indian Finance and East African Society in the Indian Ocean, c. 1840-1930.” (Ph.D. Dissertation, New York University, 2016); P. Machado, Ocean of Trade: South Asian Merchants, Africa, and the Indian Ocean c. 1750-1850 (Cambridge: Cambridge University Press, 2015); S. Bose, A Hundred Horizons: The Indian Ocean in the Age of Global Empire (Cambridge, Mass.: Harvard University Press, 2006) 72-121; C. Allen, "Sayyids, Shets, and Sultans: Politics and Trade in Masqat Under the Al Bu Sa'id, 1785-1914." (Ph.D. Dissertation, University of Washington, 1978).

18 G.F. Kunz and C.H. Stevenson. The Book of the Pearl: The History, Art, Science, and Industry of the Queen of the Gems (New York: The Century Co., 1908): 80.

19 Hopper, Slaves of One Master: 81, 86-9.

20 Fuccaro, Histories of City and State: 54-5, 93, 160-1.

21 "Annual Report on the Workings of the Bahrain Order-in-Council, 1913" (1923) IOR $\mathrm{R} / 15 / 1 / 305$. 
A central artifact of this changing labor market was the barwa-a declaration of a debt owed to the nakhoda by the mariner. A form of debt accounting, it was effectively a reverse IOU-something like a "you owe me," or more accurately a "he owes me," coupled with a request for repayment. These were chits generated as a matter of course in the maritime economies of the Persian Gulf, and were recorded on small scraps of paper no larger than $15 \mathrm{~cm}$ long and wide - often even smaller. The terms barwas laid out were brief, but clear. As one 1889 barwa read: "To whomever sees this from the nakhodas, [let it be known that] we claim from (lana 'alā) Faraj, the follower of ... sixty-five rupees and a half rupee. Whoever wants to take him on (yudimmah) [is to] hand over to us (yusallimu lanā) the aforementioned."22 Another barwa drawn up five years is virtually identical in its wording. On a sheet of paper barely the size of a matchbox it reads: "To whomever sees this from the nakhodas, [let it be known] that we claim from Hussain Al-Balushi two-hundred rupees and sixty-six rupees.... Whoever wants to take him on is to hand over the aforementioned."23 Not all barwas demanded full repayment in return for a mariner's use. Many others set out alternative terms, allowing for the mariner's new nakhoda to hand over half, a third, or a quarter of the mariner's earnings until the debt was paid off. Still others, following the same formula, declared that the mariner owed nothing, and that any nakhoda was free to take him on "in full" (kaylan). The understanding in all of these was that a nakhoda could not hire a mariner without first checking his barwa. The mariner's labor effectively belonged to his nakhoda; he had handed it over in return for a loan of money—or, as we will come to learn, more likely for store credit than for hard cash.

As the market for maritime labor in the Gulf expanded alongside the profit margins in the pearl trade, barwas served as accounting devices in a maritime sector characterized by a high degree of mobility and financed through credit. Whether the barwa was an invention of the nineteenth century labor market or an adaptation of an older form is impossible to tell; no earlier specimens exist. What we know for certain, though, is that in the late nineteenth century nakhodas in the pearl dive utilized these paper technologies to manage a mobile group of laborers, regulating their ability to move from one employer to another within the financial strictures of the Gulf maritime economy. If the presence of credit in the Gulf pearl dive was itself nothing new, nakhodas' use of instruments like these to manage the flows of labor was likely a more novel response to the changed scale of labor movement. Through barwas, they were able to track individual bodies as they moved from one ledger book to another,

22 Barwa by Ali bin Saleh Al-Dabbus, 1307 AH, Ali Ra'is Collection, Kuwait (hereafter, ARC).

23 Barwa by Nahit bin 'Ali for Hussain Al-Balushi, 1313 AH, ARC. 
using these small pieces to tether mariners to much larger information systems that accounted for loans and earnings. As the scale of labor migration, both free and forced, boomed in response to the burgeoning pearl drive, barwas offered nakhodas a way of tracking their financial outlays from one season to another-and more importantly, from one dhow to another.

It was thus credit, rather than debt, that formed the bonds that ultimately took the shape of firms that grouped mariners, nakhodas, ship-owners, and merchants together into a common enterprise. The distinction between credit and debt is not just a semantic one, even if the two are often analytically coupled together. Although both are bonds that link together past, present, and future, debt presupposes a more finite temporal horizon than credit does; it assumes repayment somewhere down the line, which credit does not necessarily imply, even as it demands "the promise of a future transfer of disposal of utilities, whatever they may be." ${ }^{24}$ And in the context of the nineteenth-century boom and the emergence of a market of seasonal laborers, credit was a way for merchants and nakhodas to channel resources towards securing the labor the firm needed to capture the new opportunities the pearling boom offered. ${ }^{25}$ We thus might see the credit regime of the pearl dive as reflecting a form of building wealth in people that animated the maritime economy of the Persian Gulf. This concept of wealth in people, which emerged out of the literature on African history, describes a phenomenon by which wealth was understood as resting in communities of people that actors would form: in the specialized knowledge that they would bring to the collective, and in the ability of the community to reproduce its social capital over the course of generations

24 M. Weber, Economy and Society: An Outline of Interpretive Sociology, vol. 1 (Berkeley: University of California Press, 1922/1978): 81. The literature on credit and debt is of course enormous; for an excellent survey of work in anthropology, see G. Peebles, "The Anthropology of Credit and Debt." Annual Review of Anthropology, 39 (2010): 225-40.

25 I borrow the notion of dhow firms from A.H.J. Prins's classic work on the maritime culture of East Africa, in which he pointed out how debt was used to bind mariners to a maritime firm comprised of a merchant, his nakhodas, and their mariners. In Lamu, debt was "part of the social organization and stabilize[d] an otherwise loose network of relations between vagrant, itinerant folk who have nothing but their muscular energy and their low skill to give and an entrepreneur who sits easily on top of the labor market," adding that "indebtedness introduces a degree of permanency in this relation, albeit indirectly, for the nakhoda is a go-between and contracting agent for the tajiri or merchant." A.H.J. Prins, Sailing From Lamu: A Study of Maritime Culture in Islamic East Africa (Assen: Van Gorcum, 1965): 214-6. In his work, Glassman takes a more expansive view of the firm, defining it as a corporate group grounded in structures of patronage, hierarchy, and credit in nineteenthcentury East Africa. Glassman, Feasts and Riot: 121-33. 
in acts that were largely aimed at venerating its ancestors. ${ }^{26}$ It was, at its core, a form of clientelism - one that self-consciously amassed the human capital necessary to undertake specific economic enterprises, and aimed to reproduce it over time.

A notion of wealth in people that regards followers as clients resonates well with what we know of economic and political life in Persian Gulf port cities. Perhaps the most established form that this took in Eastern Arabia was the tribe. From early on, the process of pearl fishing was largely managed by tribal groups, who combined their command over pools of labor with their access to political authority to concentrate much of the wealth production in their own hands. ${ }^{27}$ To supplement the labor they could draw from within their own groups, many would have added enslaved individuals to their ranks as well. And during the pearling boom, merchants took advantage of the swell in unattached immigrants, building a client base of divers and other seasonal laborers to whom they provided access to credit, housing, and work. ${ }^{28}$ These clients, for their part, allowed the merchants to shore up a political position that would balance their interests against more established corporate groups like tribesand would also give them a force to rely on in the occasional skirmishes that marked urban politics in the Gulf. ${ }^{29}$ Those who had neither slaves nor tribal followers thus could, through agile use of credit, also build up a robust clientele.

The attachments these relationships generated extended over the course of years, decades, and even generations as families of merchants, nakhodas, and mariners engaged one another in ongoing accounts and reciprocal obligations. As one observer noted, "the bond between a boat owner and his sailors was often lifelong, and even more than lifelong, for it continued in the families on both sides." In the dhow trade and the pearl dive, these ongoing bonds were "what made them the truly 'noble' occupations, based on economic position but from there extending, because of the control of men as well as money, into much wider social and political spheres." 30 But wealth in people was not simply about building a client base that could sustain a patron's position in

26 In invoking the concept of wealth in people, I draw from J. Guyer and S.M. Eno Belinga, "Wealth in People as Wealth in Knowledge: Accumulation and Composition in Equatorial Africa." Journal of African History 36/1 (1995): 91-120.

27 Fuccaro, Histories of City and State: 55-6. Historians have observed similar dynamics elsewhere in the Gulf as well: see also F. Heard-Bey, From Trucial States to United Arab Emirates (London: Longman, 1982): 199-200; T.S. Al-Rumaidhi, A'lām Al-Ghawș Ind Al-Awāzim, 1850-1950, Bi-Imārat Al-Kuwayt (Kuwait: That es-Salasil, 2006).

28 Fuccaro, Histories of City and State: 100-4; for the United Arab Emirates, see Heard-Bey, From Trucial States: 200-2, 208-11.

29 Fuccaro, Histories of City and State: 152-7.

$30 \quad$ P. Lienhardt, Shaikhdoms of Eastern Arabia (Basingstoke: Palgrave, 2001): 145-6. 
urban politics; it was also about building a strong pearling business. In this respect, a merchant's ability to bind a good nakhoda to his firm was of the utmost importance. A seasoned nakhoda knew how to navigate the offshore pearl banks with ease, and could ensure the safety of the pearling dhow-itself a major investment. Just as important, however, was the ability of the nakhoda to secure a good crew of divers and haulers-ones who had a reputation for endurance, spirit, and an ability to collect a large number of oysters. ${ }^{31}$ In the Persian Gulf pearl dive, wealth in people thus lay in the specialized forms of knowledge and skills that particular clients brought to the firm.

The firm-building strategies that merchants and nakhodas in the Persian Gulf mobilized would be immediately recognizable to historians working on other parts of the Indian Ocean, particularly the East African coast. There, as scholars have long pointed out, coastal merchants made prodigious use of credit to bind planters, porters, and other clients into their business enterprises over the course of the eighteenth and nineteenth centuries. ${ }^{32}$ And as the opportunities for wealth accumulation expanded, so too did the use of credit instruments, many of which similarly sought to bridge together past, present, and future obligations. These financial transactions, historians have argued, worked alongside — and sometimes outright challenged — the bonds of patronage, kinship, and affect that had long structured economic activity in the region. ${ }^{33}$ In East Africa, much as in the Gulf, actors mobilized paper technologies in order to bring together human and financial capital in a changing commercial arena.

And yet, its family resemblances to other instances of patronage and credit around the Indian Ocean should not divert our attention from the fact that the relationship expressed in the barwa could lead the actors involved down an unsavory path. For rather than reflecting the robust and multiplex bonds that characterized a notion of wealth in people, the barwa compressed them into a single value - that of the credit advanced to the diver. As the industry became reliant on a seasonal, itinerant body of laborers, then, the attachments that characterized work in the maritime economy were flattened into financial ties, which could then be transferred to someone else altogether in return for financial satisfaction. This was not always insidious. Fungibility was the precondition for the very sort of labor mobility that characterized much

31 Al-Shamlan, Tärīkh Al-Ghawș, 1: 376; P.W. Harrison, The Arab at Home (New York: Thomas Y. Crowell, 1924): 75-6.

32 Glassman, Feasts and Riot; Machado, Ocean of Trade: 18-68.

33 Bishara, A Sea of Debt; McDow, Buying Time; McMahon, Slavery and Emancipation in Islamic East Africa: 147-55; Wint, "Credible Relations." 
of the maritime economy, and may ultimately be why formerly enslaved divers like Sa'id bin 'Ali would approach the Political Agent to ask for a barwa; it allowed them to enter into the marketplace of obligations. At the same time, though, the fact that mariners were convertible - that they could ultimately be abstracted into the value of their debts, rather than even their labor-suggests how people, property, and capital could all shade into one another. For at certain junctures wealth in people had to be converted into, or put up as collateral against, other equally fungible forms of wealth. But to get there, we have to step off the dhow and into the bazaar.

\section{The View from the Shop}

Seen from the bazaar, the dhow looked less like an insular firm adrift at sea than it did an extension of the marketplace. The ties of capital, credit, and commodities that circulated between the deck of the dhow and the bazaar during the nineteenth century rendered the ship an integral part of the fabric of the marketplace; the individuals who bridged the two domains only further reinforced the blurred distinction between one and the other. Moreover, it was in the bazaar - and in the shop specifically - that the forms of wealth in people that characterized the deck of the dhow bled into wealth in property as barwas, ledger books, and other instruments of the credit economy intersected with one another, at times producing a relationship that looked a lot less like credit and a lot more like debt.

A view from the shop makes it clear that the barwa was not for the dhow alone; rather, it acted as an entry ticket into the world of the bazaar. What looked like wealth in people from one perspective appeared as access-as a mediated form of wealth in things - from another. For the divers who entered into the dhow firm, barwas reflected their ability to borrow from different nakhodas, within the strictures of the credit market. Attachment to a nakhoda and merchant endowed the itinerant diver with a creditworthiness that he might not have otherwise enjoyed. It gave him personhood-social and legal standing - in a port town where he would have otherwise been a stranger. Shorn of the ties to kin that tribesmen and other long-standing residents would have enjoyed, the waves of seasonal divers attached themselves to their merchant- or nakhoda-patrons; their credit stood in for their social standing.

It is telling that the barwa was written up as a declaration by the nakhoda on behalf of the diver, when virtually all other debt acknowledgments were in the first person, by the borrower; for in it, the nakhoda spoke as the mariner's bazaar patron. Through their patrons, seasonal mariners gained access 
to food-principally rice, but also sugar and tea — and money that they would not have otherwise had. ${ }^{34}$ Dry goods like rice constituted the life-blood of the Gulf marketplace; they circulated back and forth between merchant, mariner, and nakhoda, and often stood in for all other forms of credit. When a mariner took on a loan, it was invariably in rice, not money; those who wanted to convert it into money had to hawk sacks of rice around the marketplace or sell them back to the merchant at a discounted rate. The credit regime that bound the Gulf pearl dive to the Indian Ocean marketplace was thus fueled by commodities from that very world, as rice from India was converted, through barwas and sheets in the ledger book, into credit.

The link between the two markets was, of course, the merchant. Much like how the diver found in the nakhoda his gatekeeper to the maritime credit economy, the nakhoda saw in the merchant his bazaar patron. Pearl merchants kept their accounts open with the nakhodas they employed, giving them access to their stores. One observer noted that although there were independent operators in the maritime economies of the Persian Gulf, he "was in fact no highly respected or envied character," adding that "it was the lesser people in the pearling industry who sold their pearls to anyone without having a standing arrangement with a particular merchant." ${ }^{35}$ A nakhoda who agreed to a merchant financing his voyage - and there were few who had the means to finance a voyage, with all of its provisions, on their own - attached himself to that merchant in two different ways. First, he was expected to give that merchant the right of first refusal on the season's catch, and was obliged to sell that catch at a rate 20 percent below market value. ${ }^{36}$ At the same time, however, he agreed to provision the dhow with supplies from that merchant's store, usually at a 2o percent mark-up. These provisions, at least some of which nakhodas were sometimes compelled to take as partial payment for the season's catch, would then be re-sold in the market, often for less than they were worth, "and this is added to the small sum of ready money which has been paid by the Musaygum

34 The historian Rashid Al-Zayyani gives a detailed description of a process by which a diver would fictitiously buy (on credit) bags of rice from a merchant and then "sell" them back to him at a price lower than he bought them for, effectively amounting to a loan with interest. Al-Zayyani, Al-Ghawș wal-Tawāshah: 171-3.

35 Lienhardt, Shaikhdoms of Eastern Arabia, 158.

36 "Notes on the Pearl Fisheries of the Persian Gulf," IOR V/23/32 no. 152: 31-2. An 1818 report has the markup at 10 percent, but 20 percent seems to be the more widely corroborated figure, even for the 19th century. Robert Taylor, "Extract from Brief Notes Containing Historical and Other Information Connected with the Province of Oman; Muskat and the Adjoining Country; the Islands of Bahrain, Ormus, Kishm, and Karrack; and Other Ports and Places in the Persian Gulf," (1818) IOR R/15/1/732: 40. 
[the local pearl merchant]."37 Together, these worked to bind the nakhoda and crew into the merchant's firm - dhow, shop, and all.

And it was the maritime firm that acted as the organizational carapace, binding mariners to nakhodas and nakhodas to merchants, but also structuring the movement of goods, the division of profits, and the apportionment of obligations between its different members. After the "purchase price" of the pearls had been agreed upon and the dhow's expenses deducted from the gross profits, the pearl merchant, dhow owner (often, though not always, the merchant himself), and crew (including the nakhoda) divided the net profits in agreed-upon proportions. ${ }^{38}$ The division of shares worked to bring labor and capital together, bridging the uncertainties of a maritime economy with the demands for certainty and calculability that the marketplace demanded. Like the sacks of rice that ultimately made their way to the mariners, the fished pearl traveled through the bonds of debt and obligation that brought different actors together and across the loose sheets of paper and ledger books that enabled its transformation from one form of wealth to another, echoing back and forth between the bazaar and the dhow.

But alongside the barwas and ledger books that bound actors together into firms ran another paper regime, one that sought to secure the debts

37 "Notes on the Pearl Fisheries of the Persian Gulf," IOR v/23/32 no. 152: 30. One early nineteenth-century report estimated the amount of profit that merchants gained from these to be no less than 5 o percent, and often as high as 100 percent; Taylor, "Extract from Brief Notes," IOR R/15/1/732: 40. And though early twentieth-century accounts suggest lower rates of profit, the arrangement was no less a part of pearling finance than it was a century earlier; Political Agent, Bahrain, to Gulf Resident, Bushire (31 March 1924) IOR $\mathrm{R} / 15 / 1 / 132: 47-9$.

38 As a principle, profit-sharing was widespread in the maritime economies of the Western Indian Ocean more broadly. The most basic form emerged out of arrangements between fishermen, who devised ways of splitting up the proceeds from a day's catch between the fishermen and the owner of the fishing equipment—often a fisherman himself. See also Lienhardt, Shaikhdoms of Eastern Arabia: 125-135. In East Africa, too, profits from fishing dhows were split between mariners, captains, and boat owners in agreed-upon proportions; Prins, Sailing from Lamu: 163-70. As the activity increased in complexity, involving a wider variety of actors and more financing, the division of shares and bonuses better reflected this shift. In pearl fishing and the dhow trade, actors allotted shares for dhow owners, nakhodas, and mariners of different ranks, including first mates, divers, haulers, and cooks. Agius, Seafaring in the Arabian Gulf and Oman: 152-4; Al-Hijji, Kuwait and the Sea: 46-7, 84-6; Villiers, Sons of Sinbad: 401-2. Profit-sharing was characteristic of many Islamic partnerships as well, but I hesitate to emphasize the point here; there is nothing about the maritime economy of the Gulf that suggests that it conforms in any way to partnership institutions enshrined in figh texts-or that it ought to. On profitsharing arrangements in Islamic law, see Abraham Udovitch, Partnership and Profit in Medieval Islam (Princeton: Princeton University Press, 1970). 
against other more market-ready forms of wealth. For nearly every loan that was handed out-particularly between transregional merchants and their local partners, but also between the local pearl merchants, nakhodas, and mariners-debtors put up urban and rural property as security. The market for credit, and all of the advances of rice and other foods that animated it was thus underpinned by a robust market for property and a changing contractual menu of pledges, mortgages, and other forms of property hypothecation. Many of the contracts that Bahraini merchants drew up refer to debts owed for bags of rice - the bag was called a jūniya or güniya, referring to the gunny sack in which it came - at least some of which made their way down the credit chain to nakhodas and divers. In one from 1914, a Bahraini merchant acknowledges a debt to an Indian firm of Rs 15,000, and acknowledges having received 1,00o bags of rice; as security, he mortgaged a house in one of Bahrain's urban quarters. Another contract from 1917 acknowledged a debt of Rs 7,600 for 400 bags of rice, and mortgaged four storehouses. ${ }^{39}$ Other similar transactions took place in later decades as well, between Arabs, Persians, and Indians, as the nexus between credit and property began to make itself more visible in the maritime marketplace. ${ }^{40}$

Though most of the extant debt deeds make no reference to the reason behind the transactions in question, a handful of the registered contracts do make explicit reference to a pearling-related loan. One Indian merchant registered a 1915 deed at the British Consulate in which a local Bahraini merchant acknowledged a debt of Rs 2,516; the borrower agreed to repay the amount at the close (gufäl) of the pearling season. ${ }^{41}$ In another contract from 1928 , another local merchant acknowledged a debt of nearly Rs 70o, which he agreed to pay back in instalments at the end of every pearling season. To secure the loan, he pledged a house that he owned for a period of five years. ${ }^{42}$ Others specifically linked pearling-related loans to bags of rice that borrowers received. ${ }^{43}$

The forms of wealth that they pledged weren't always local, nor were they always whole; economic actors in the pearl dive looked to whatever property they had at their disposal to drum up credit. For merchants in Bahrain, the oasis towns in Hasa, on the coast of the Arabian Peninsula opposite the island, often served as a productive hinterland on which they could draw when accessing a loan. When a pearl merchant turned to his creditor to finance a pearling

39 IOR R/15/2/2O17: 55 , 12 O.

40 IOR R/15/2/2O18: $5^{-1} 3$.

41 IOR R/15/2/2O17: 73 .

42 IOR R/15/2/2O18: 19.

43 See the deeds reproduced in Al-Zayyani, Al-Ghawṣ wal-Ṭawāshah: 174-7. 
voyage in 1914, he hypothecated to him five different plots in plantations that his family owned in Qatif, for the whopping price of nearly Rs 65,00o. And when one Bahraini pearl merchant found himself in economic straits a few years later, he hypothecated to an Indian firm his wife's shares in her family's date plantations: $3 / 164,5 / 72$, and 25/140 shares in three different Bahraini plantations, and 1/26 shares in a date plantation in Qassim in Central Arabia, as well as shares in family properties around Manama. Bazaar transactions, then, drew on forms of wealth that came from well beyond the space of the marketplace itself.

Looking out from the shop, then, it becomes clear that the barwa as an instrument did not exist on its own. Rather, it was embedded in a much broader world of credit, goods, property and paper that moved through the firm and around the maritime bazaar during this time. Reading the barwa from the shop thus illustrates the ways in which the two forms of wealth, in people and in things, necessarily circulated alongside one another as merchants, nakhodas, and mariners all sought to insert themselves into the changing maritime credit economy —one in which paper came to play an increasingly important role.

\section{The Agency and the Bazaar}

By the time Sacid bin 'Ali walked into the British Political Agency and asked for a manumission certificate and a barwa, there were scores of others like him, all of whom faced the same problem: no nakhoda would employ them without first ascertaining whether or not they were indebted to another nakhoda. Sa'id, like many of the others, had run away from his master to ask for manumission, and thus enjoyed none of the attachments and bonds that located him on the island; formerly enslaved people like him were effectively locked out of the maritime bazaar. In approaching British officials for manumission certificates and barwas, they drew the Agency into the regional marketplace of obligation. And despite their misgivings surrounding the status of the slaves - were they genuinely runaway slaves or just divers who had absconded, and were they really debt free?-British Agents around the Gulf began issuing barwas as a matter of regular business. ${ }^{44}$ Shorn of attachments, manumitted slaves like Sacid looked

44 As early as 1917, the Deputy Political Resident wrote that "The whole fabric of the pearling industry will collapse if any diver when he gets badly into debt can run away and escape his liabilities by the simple process of saying he is a slave. It is thus obviously not advisable to do anything to encourage the breaking of the pearling usage or to give colour to the idea that we are ready to assist runaway divers to evade their debts." Deputy Political 
to British officials on the island as their temporary patrons, to guarantee their creditworthiness until they could build up a marketable past of their own.

But for British officials on the island, the arrival of manumitted slaves like Sa'id raised an uncomfortable set of issues. The distinction between wealth in people and wealth in things was not always a clear one; at times they sat a little too close to one another. When the property that merchants and nakhodas put up as collateral against the loans they took was not enough, they looked to their financial outlays-to the mariners themselves. One British official pointed out as early as the 1870s that "the whole boat's crew is more or less in debt to the Nakhoda as he himself is to the Bunneah [the Bania - a term used to refer to Hindu merchants around the Indian Ocean] so that when it suits the latter to sell up a Nakhoda rather than await payment of the debt by instalments, he does so to the extent of the boat and the crew." 45 In those moments, the truncated ledger-book value of a mariner could become a commodity in itself; the barwa could ultimately compress the diver into a transferable, or even saleable, commodity. Through different forms of documentation, from simple barwas to more elaborate debt contracts and ledger books, the denizens of the pearling bazaar blurred the distinction between wealth in people and wealth in property so as to capture increasing gains or stave off commercial ruin. People may have been the ultimate source of wealth in the pearling firm, but as the fortunes of different merchants and their clients became more firmly linked to regional and global markets, and as the ties of debt increasingly formed the core logic of the bazaar world, wealth in people often had to be abstracted, pawned, and sometimes ultimately liquidated.

At least some of the contracts from the early twentieth century point to the blurry line between people and property. As security against his Rs 39,0oo debt to his Indian creditor, for example, one Bahraini pearl merchant mortgaged two houses belonging to him and two belonging to his wife, but also outstanding debts from several nakhodas. The deed made sure to include a clause which stated that the debts of the divers were not to transfer over-a point that would have made the contract look precariously close to something akin to the sort of slavery-related financing British officials worked to stamp out in East Africa. ${ }^{46}$ The tension between credit and debt had always been baked into the bond, and what may have appeared, in one context, as a relationship

Resident, Persian Gulf to Political Agent, Muscat (11 June 1917) IOR R/15/1/202: 15. See also Zdanowski, Speaking with their Own Voices: 79-82.

45 "Notes on the Pearl Fisheries of the Persian Gulf," IOR V/23/32 No. 152: 31.

46 IOR R/15/2/2017: 50A, 123, 38. On slavery and finance in East Africa, see also A. Sheriff, Slaves, Spices, and Ivory in Zanzibar (Athens, OH: Ohio University Press, 1987): 201-44; Wint, "Credible Relations." 
of credit—of channeling resources to capture opportunity-might, given changed circumstances, begin to more closely resemble the burden of debt.

We see these contracts because they were registered at the British consulate by the creditors - $\mathrm{a}$ fact that suggests a much broader phenomenon that lurked behind the bazaar's contracts and conversions. For with the pearling boom and the growing involvement of British Indian subjects in the pearl dive, the interlinked markets for labor, credit, and property increasingly came under the purview of Bahrain's British officials. From early on, it became clear to them that the involvement of Indian merchants in financing the pearl trade would draw them in. In both Muscat and Bahrain, the Government of India delegated responsibility for the settlement of British subjects' commercial disputes to its "Native Agents" - prominent local merchants who represented the British Indian government in local affairs. Over time, the British Government decided to replace these local representatives with salaried British officers. In Bahrain, the last Native Agent was replaced in 1899, and a Political Agent's court was up and running soon afterward.$^{47}$ With its declaration of jurisdiction over non-Bahrainis in 1905, the intertwining of the Agency into the fabric of the pearling industry was all but complete. ${ }^{48}$

The establishment of a formal British juridical presence in the pearl dive created as many problems as it resolved. As long as times were good, credit flowed and there was no need for a merchant or nakhoda to liquidate his client base in order to meet his obligations. But times could not always be good, and British officials who looked to enforce their subjects' contracts inevitably confronted the uncomfortable boundary between wealth in people and property in a credit regime that was beginning to much more closely resemble debt bondage. The very fact that an Indian merchant in the 187 os could choose to "sell up a Nakhoda rather than await payment of the debt by instalments," and that another could ask his debtor in 1914 to secure a loan through a mix of real estate and outstanding debts, is at least in part a result of their confidence that the British Agents would enforce their claims on others. An unintended consequence (and a deeply ironic one) of the gradual juridical entrenchment of British Indian officials in the maritime bazaar, and their commitment to

47 Onley, The Arabian Frontier of the British Raj: 192-200.

48 Fuccaro, Histories of City and State: 123; Bishara, "A Sea of Debt": 342-403; H. Al-Baharna, British Extraterritorial Jurisdiction in the Gulf, 1913-1971 (Slough: Archive Editions, 1998); H.A. Radhi, Judiciary and Arbitration in Bahrain: A Historical and Analytical Study (London: Kluwer Law International, 2003): 19-36; L. Stephenson, "Re-Routing the Persian Gulf: The Transnationalization of Iranian Migrant Networks, c. 1900-1940.” (Ph.D. Dissertation, Princeton University, 2018): 124-55. 
enforcing the property rights of their subjects and protégés, was that it set in motion the very processes by which forms of credit could cross the threshold into the realm of debt; wealth in people could become a form of wealth in things.

With the entry of manumitted slaves into the maritime credit economy, the blurred distinctions between people and property became even more problematic than they had been in the past. Though officials ultimately had no recourse but to issue the petitioners with barwas that would allow them to take on loans - the alternative was a body of manumitted slaves who could not support themselves - they acknowledged that in doing so they allowed for the possibility for recently-freed slaves to be passed around from debtors to creditors in a system that, from their perspective, was hardly distinguishable from slavery. A British report in the 187 os suggested that once a nakhoda took a loan from his merchant to outfit a voyage he was "emphatically no longer free," adding that "once in that gentleman's books it is not easy to make hauls large enough to get out of them again."49 Another in 1924 echoed the sentiment, writing that nakhodas' moneylending "practically enslaves the diver" by keeping him in a cycle of debt. ${ }^{50}$ And an American traveler in the Gulf in the early 1920 made a more explicit comparison, declaring that a diver who took on loans from his nakhoda became "a slave for the rest of his life," and suggesting that "it is probably easier for a negro slave on the Pirate Coast [the coast of what is today the United Arab Emirates] to escape than it is for a Bahrain slave to regain his freedom."51

The perceived slave-like condition of indebted divers, coupled with an influx of enslaved and recently-manumitted divers into the industry, created an unsavory composite portrait in the minds of officials and observers alike. Their reports suggest that the finance regime was designed so that it was ultimately the diver's body that was made to absorb the uncertainties of a pearling season, and his body that ultimately served as insurance to guarantee the merchant's accumulation of wealth. ${ }^{52}$ The diver was essentially his labor; no more, no less. Debt was a tool mobilized by duplicitous nakhodas and merchants to keep divers in a state of bondage. It robbed divers of their personhood, understood as their ability to freely move from one employer to another; it turned them into property to be pawned between different nakhodas at will. That mariners

49 Durand, "Notes on the Pearl Fisheries of the Persian Gulf," IOR V/23/32: 31.

5O Political Agent, Bahrain, to Gulf Resident, Bushire (31 March 1924) IOR R/15/1/132: 48.

51 Harrison, The Arab at Home, 80.

$5^{2}$ Here I am borrowing from the compelling phrasing of Markus Rediker in Between the Devil and the Deep Blue Sea: Merchant Seamen, Pirates and the Anglo-American Maritime World, 1700-1750 (Cambridge: Cambridge University Press, 1987): 145. 
were itinerant and lived in makeshift huts just outside of town — much like the formerly enslaved did in East Africa—only underscored the point. ${ }^{53}$

Faced with a growing chorus of discontentment with a set of arrangements that held the potential to deeply embarrass them, British officials in Bahrain began laying the groundwork for a series of reforms to the pearl dive-and specifically to the financial regime that underpinned it. The reforms were broad in scope: they mandated that nakhodas and mariners use newly-printed account books that would be verified by a third party, laid out clear rules on the financing of dhows and on consent in the sale of the season's catch, and established channels of dispute resolution for actors who were unhappy with any part of the process. ${ }^{54}$ The principal goal of the reforms, virtually everyone agreed, was to do away with the debts that had characterized the dive. Bernard Stuart-Horner, the secretary to the Gulf Resident, articulated the goals of the reforms most clearly in a report written in 1926: "The State is at present aiming at the gradual elimination of the system whereby the divers are kept permanently in debt," he wrote, adding that "there is no doubt that in a few years, if the system be persevered in, almost all the divers will be out of debt and the accounting system will then be reduced to such a simple form that the few disputes which could arise would be immediately settled." His writings echoed the sentiments of most officials on the island and around the Gulf. What distinguished Stuart-Horner, though, was that he could historicize the prevalence of debt in the pearl dive, even though he could not see past it. In his view, pervasive indebtedness was the product of a pearling boom that led to an insatiable demand for divers and, by extension, rising competition between nakhodas to secure the labor they desired. Though rising advances seemed like they might be to the benefit of the divers, "all that had really happened was that the original cost of enslaving a diver for life had risen owing to competition, but the divers were hopelessly tied up and in reality worse off than formerly when occasionally an energetic man could work in the off season and pay off the debt and free himself."

More than other officials, Stuart-Horner made clear here his ideological assumptions. At its core, his statement assumed that if they had the choice, divers would choose to be free of any financial obligations, and that prior to the marketization of labor an individual diver could and did rid himself of them. The regulations were thus making it easier for divers to work themselves out of debt, and ultimately (or so he and others hoped) into a situation wherein University Press, 2011): 61-5. 
they could move freely from one employer to another-a perfect form of free labor. Nakhodas would have to compete with one another for good divers "by fairer treatment, that is by paying the diver his fair earnings," and Bahrain would ultimately benefit. "The first result of improved conditions," declared Stuart-Horner, "would be for divers to tend to come to Bahrain, where they can get a square deal." ${ }^{55}$ His thinking paralleled that of others around the Western Indian Ocean - in India, and in East Africa, where British officials worked to undo the bonds of debt that brought together different economic actors and replace them with a more market-guided logic of economic life. ${ }^{56}$ In the Persian Gulf, as elsewhere, they did this through a series of regulations targeting economic practices that they understood as falling outside of that market logic. ${ }^{57}$ The irony, of course, was even as he understood indebtedness in the Gulf pearl dive as being a product of historical processes, he elided the sizeable role that British juridical practices in the region played in producing the very phenomenon they sought to eradicate.

Nakhodas immediately objected to the measures. A number chose to leave Bahrain altogether, moving to neighboring Qatar as a protest against the diving reforms. ${ }^{58}$ Those who stayed behind flooded the Ruler and Political Agent with complaints: between September and November 1925, no fewer than fifty different nakhodas submitted petitions bewailing the injustices of the new system, and the strain it placed on their precarious position. In one such petition, thirty nakhodas wrote that due to the reforms there were "no more merchants giving out money and no nakhodas readying dhows" and that "work has stopped and fortune has decreased." They asked that they retain the right to directly punish divers for disobedience, to pursue and capture absconders, and to arrest and punish divers who reneged on their promise to dive-in sum, that "the affairs [be left] with those who are in authority [al-amr li-man lahu al-amr]." Although they expressed concern about the changes to accounting practices, they were much more alarmed about the limits placed on their ability to manage and police the wealth in people that they had helped accumulate. ${ }^{59}$ Faced with an erosion of their position as patrons and masters to divers, nakhodas

55 Secretary to the Gulf Resident to the Political Agent, Bahrain (20 February 1926) IOR R/15/2/132: 131-6.

56 Bishara, A Sea of Debt: 225-39.

57 On regulation and capitalism in the Arabian Sea, see J. Mathew, Margins of the Market: Trafficking and Capitalism across the Arabian Sea (Berkeley: University of California Press, 2016).

$5^{8}$ Political Agent, Bahrain, to Gulf Resident (17 September 1925) IOR R/15/12/132: 118-22.

59 Petition by 30 nakhodas (27 September 1925) IOR R/15/12/132: 123 . 
argued for the preservation of at least some of their customary rights within the carapace of the maritime firm.

Ultimately the nakhodas' protests fell on deaf ears. This was, in part, because of their context: the falling profits into the 193os, brought about largely by the onset of the worldwide economic depression, eroded away the last pockets of resistance to the new regime. ${ }^{60}$ The divers, for their part, might have been happy to accept the nakhodas' authority in return for continued access to the market, but were unable to do so-in part because of the shift in the discourse surrounding debt among the dive's regulators, and in part because of broader economic transformations - in any case, for reasons beyond their own control. That takes us a little too far ahead in the narrative, though; there were more immediate, and ultimately more revealing, reactions to the transformation of labor finance in the pearl dive.

\section{4}

\section{Reflections from the Waterfront}

On December 30 1926, a group of 200 divers sailed out to the neighboring island of Muharraq, where members of Bahrain's ruling family, the Al-Khalifa, resided. Upon their arrival, a British official noted, they "went to the house of an usurer, helped themselves to his rice, and destroyed his records." ${ }^{61}$ One Bahraini merchant, 'Ali Al-Zayyani, described the event in a letter to his trading partners in Kuwait: "the pearl divers have attacked the marketplaces of Muharraq and Manama, and have taken foodstuffs, rice, and dates," he wrote. "In Muharraq, they attacked the shops (dukākinn) of the sayyids and took from them rice, and also tampered with their safes but were unable to open them. They then tore up whatever they could find from the safes and ledgers, and other [papers]" - among which, no doubt, were at least a handful of barwas. ${ }^{62}$

As the divers tore up the paper trail that had brought them into the 1920s, they ripped a gaping hole in the fabric of the bazaar. Their actions brought together dhow, shop, and government into a roughly-arranged worldview. For social historians, this vignette is all too familiar, reminiscent as it is of the bread

6o On the worldwide economic depression and its repercussions in the Gulf pearl dive, see also Hopper, Slaves of One Master: 191-6; Bishara, "A Sea of Debt": 452-63.

61 Political Agent, Bahrain to Secretary to the Gulf Resident (1 January 1927) IOR R/15/2/ 132: 152 .

62 'Ali bin Ibrahim Al-Zayyani, Bahrain, to Fahad Al-Khalid and his brothers, Kuwait (4 January 1927), published in A. Al-Ghunaim (ed.) Wathā'iq Min 'Așr Al-Lu'lu' (Kuwait: Center for Research and Studies on Kuwait, 2017): 61-2. Six years later, another riot took place, and on a much larger scale; see IOR R/15/2/848: 5 . 
riots that animated E.P. Thompson's seminal work on moral economy: swap out bread for credit and the cold North Atlantic weather for the humidity of a Bahraini summer, and the scene begins to look like one we already know well. ${ }^{63}$ Much like Thompson's working class, the divers in Bahrain protested against what they saw were attempts to reduce their customary right to pre- and postseason advances - ultimately, their right to credit.

What is remarkable, though, is that as all of this was happening, manumitted slaves still poured into the Agency asking for barwas so that they could go find work in the maritime sector; Sacid bin 'Ali himself walked into the Agency just fifteen months after the diver uprising. If we read that moment, alongside the divers' actions, as them unwittingly ensnaring themselves in debt, then they are difficult scenes to make sense of together. However, we might read them differently. Both in the Agency and along the waterfront, these individuals were asking for the right to participate in the maritime economy — for the right to credit and to form the attachments that would allow them full inclusion in the bazaar. Whether they had always been free, enslaved, or had recently been manumitted made no difference to the fact that many would have straddled the uneasy boundary between people and property at least once in their lifetimes. The only distinction between those who were free and those were not was that by the late 1920 one group, the formerly enslaved, could draw on the British Agency to facilitate their entry into the credit economy, while the other, the freeborn, could only tear a temporary breach into the patchwork of people, papers, and goods that had established the parameters of their economic lives. And even that distinction was not always clear. When the divers looted the bazaar yet again in 1932, Sacid bin 'Ali and the scores of manumitted slaves may well have formed part of the crowd of what one official derisively called "ruffians and semi savages from a dozen different countries without, for the most part, any families present to restrain them." ${ }^{\prime 4}$

Contests over credit and paper like those that characterized Bahrain in the 1920 lay bare the world of the maritime bazaar. Through them, we see how the ties of credit that gave the marketplace its shape came to be remade in the face of regional transformations, but also how their entanglement in an imperial legal world could set in motion processes that might ultimately redefine them. As merchants from around the Persian Gulf and India formed constellations of people, property, and paper around a changing juridical landscape,

63 E.P. Thompson, "The Moral Economy of the English Crowd in the Eighteenth Century." Past and Present 5o (1971): 76-136.

64 Political Agent, Bahrain, to Political Resident, Persian Gulf (30 May 1932) IOR R/15/2/848: 9,15 . 
the bazaar emerged as a site of competing ideologies and worldviews, in which different visions of economic life jostled with one another.

If the tensions of the 1920 involved lofty discourses of rights, freedoms, and political economy, those discourses invariably anchored themselves in concerns over mundane pieces of paper like barwas. Historians might be forgiven for having ignored them altogether. Hardly any have survived in the archives, and those that have made their way into various private collections do little to inspire any historical analysis. Read separately from the world of the bazaar, they are mere curiosities; fragments of an undifferentiated past, in which debt and hardship were an endemic and unchanging feature of the maritime economy, rather than historically specific one. Making sense of them as artifacts of history requires that we set them back against the backdrop to which they belonged - to bring back the goods they circulated alongside, the associations they gave rise to, and ultimately, the anxieties they produced.

\section{Appendix}

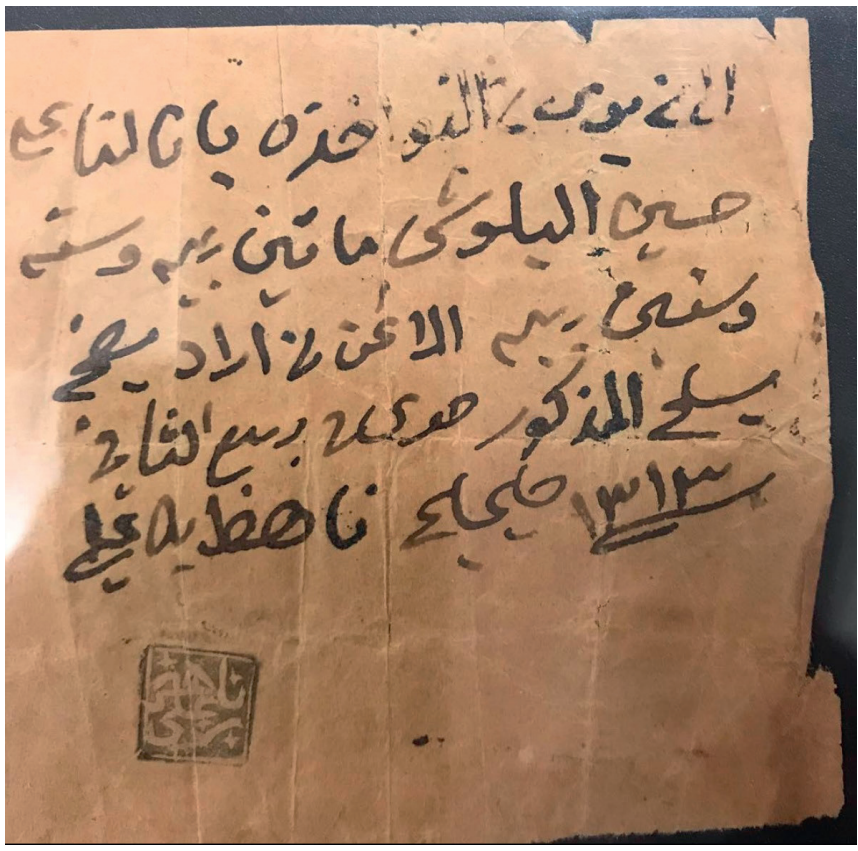

FIGURE 1 


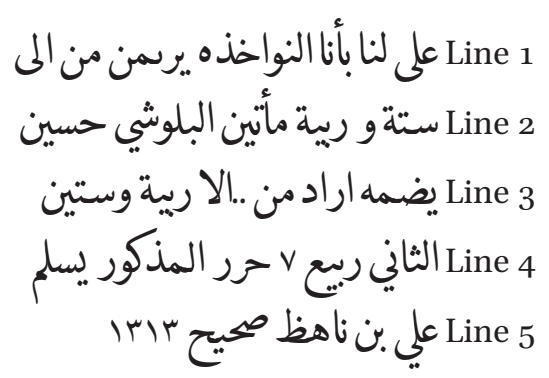

Line 1: To whomever sees this from the nakhodas (dhow captains) [let it be known] that we claim from

Line 2: Hussain Al-Balushi two-hundred rupees and six

Line 3: and sixty rupees.... Whomever wants to take him on

Line 4 : is to hand over the aforementioned. Written on 7 Rabi $^{c} \mathrm{Al}-T h a n i$, Line 5:1313 [27 September 1895]. Verified [i.e. signed], Naheḍ bin 'Ali [Affixed seal]

\section{Acknowledgements}

I am grateful to the European Research Commission and the Lawforms project which provided funding for the research presented in this article. I would also like to thank Nandini Chatterjee, Samira Shaikh, Lyman Stebbins, and the two anonymous reviewers for their valuable input, and Dominic Vendell and Elizabeth Thelen for their help. I thank the European Research Commission and the Lawforms project for providing funds to publish this article, and the entire issue, in Open Access format.

\section{Bibliography}

\section{Abbreviations}

ARC Ali Ra'is Collection, Kuwait

IOR India Office Records

\section{Arabic}

Al-Ghunaim, Abdullah, ed. 2017. Wathā'iq Min 'Așr Al-Lu’lu'. Kuwait: Center for Research and Studies on Kuwait.

Al-Hijji, Yacoub Y. 1993. Nawākhithat Al-Safar Al-Shirā̄̄ Fì Al-Kuwayt. Kuwait: Al-Rubay'ān Publishing. 
Al-Rumaidhi, Talal Sa'ad. 2006. A'lām Al-Ghawș Ind Al-Awāzim, 1850-1950, Bi-Imārat Al-Kuwayt. Kuwait: That es-Salasil.

Al-Shamlan, Saif Marzouq. 1975/1986. Tarikh Al-Ghawș 'Ala Al-Lu'lu' Fi Al-Kuwayt Wal-Khalï Al-'Arabi, 2 vols. Kuwait: That es-Salasil.

Al-Zayyani, Rashid. 200o. Al-Ghawș wal-Ṭwāshah. Manama, Bahrain: Al-Ayyam Publishing.

\section{English}

Allen, Calvin. 1978. "Sayyids, Shets, and Sultāns: Politics and Trade in Masqat Under the Āl Bū Saīd, 1785-1914." Unpublished Ph.D. Dissertation, University of Washington.

Al-Baharna, Hussain. 1998. British Extraterritorial Jurisdiction in the Gulf, 1913-1971. Slough, UK: Cambridge Archive Editions.

Bhacker, M. Reda. 1994. Trade and Empire in Muscat and Zanzibar: Roots of British Domination. London: Routledge.

Bishara, Fahad Ahmad. 2012. "A Sea of Debt: Histories of Commerce and Obligation in the Indian Ocean, 1850-1940." Unpublished Ph.D. Dissertation, Duke University.

Bishara, Fahad Ahmad. 2017. A Sea of Debt: Law and Economic Life in the Western Indian Ocean, 1780-1950. Cambridge: Cambridge University Press.

Bishara, Fahad Ahmad. and Hollian Wint. 2020. Into the Bazaar: Indian Ocean Vernaculars in the Age of Global Capitalism. Journal of Global History 16/1: 44-64.

Bissell, William. 2011. Urban Design, Chaos, and Colonial Power in Zanzibar. Bloomington: Indiana University Press.

Bose, Sugata. 2011. A Hundred Horizons: the Indian Ocean in the Age of Global Empire. Cambridge, MA: Harvard University Press.

Campbell, Gwyn and Alessandro Stanziani, ed. 2013. Bonded Labour and Debt in the Indian Ocean World. London: Pickering \& Chatto.

Campbell, Gwyn and Alessandro Stanziani. 2013. Debt and Slavery in the Mediterranean and Atlantic Worlds. London: Pickering \& Chatto.

Carter, Robert. 2012. Sea of Pearls: Seven Thousand Years of the Industry that Shaped the Gulf. London: Arabian Publishing.

Falola, Toyin and Paul Lovejoy, ed. 1994. Pawnship in Africa: Debt Bondage in Historical Perspective. Boulder: Westview Press.

Fanselow, Frank. 199o. The Bazaar Economy, or How Bizarre is the Bazaar Really?. Man 25/2: 250-265.

Floor, Willem. 2007. The Persian Gulf: The Rise of Gulf Arabs, The Politics of Trade on the Persian Littoral, 1747-1792. Washington, DC: Mage Publishers.

Fuccaro, Nelida. 2009. Histories of City and State in the Persian Gulf: Manama since 1800. Cambridge: Cambridge University Press.

Geertz, Clifford. 1978. The Bazaar Economy: Information and Search in Peasant Marketing. American Economic Review 68/2: 28-32. 
Glassman, Jonathon. 1995. Feasts and Riot: Revelry, Rebellion and Popular Consciousness on the Swahili Coast, 1856-1888. London: James Currey.

Guyer, Jane and Samuel M. Eno Belinga. 1995. Wealth in People as Wealth in Knowledge: Accumulation and Composition in Equatorial Africa. Journal of African History 36/1: 91-120.

Harrison, Paul W. 1924. The Arab at Home. New York: Thomas Y. Crowell.

Heard-Bey, Frauke.1982. From Trucial States to United Arab Emirates. London: Longman.

Al-Hijji, Yacoub H. 2010. Kuwait and the Sea: A Brief Economic and Social History. London: Arabian Publishing.

Hopper, Matthew. 2015. Slaves of One Master: Globalization and Slavery in Arabia in the Age of Empire. New Haven: Yale University Press.

Keshavarzian, Arang. 2007. Bazaar and State in Iran: The Politics of the Tehran Marketplace. Cambridge: Cambridge University Press.

Kunz, George Frederick and Charles Hugh Stevenson. 1908. The Book of the Pearl: The History, Art, Science, and Industry of the Queen of the Gems. New York: The Century Co.

Lienhardt, Peter. 2001. Shaikhdoms of Eastern Arabia. Basingstoke: Palgrave.

Lovejoy, Paul and David Richardson. 2001. The Business of Slaving: Pawnship in Western Africa, c. 1600-1810. Journal of African History 42/1: 67-89.

Machado, Pedro. 2015. Ocean of Trade: South Asian Merchants, Africa, and the Indian Ocean c. 1750-1850. Cambridge: Cambridge University Press.

Mathew, Johan. 2016. Margins of the Market: Trafficking and Capitalism across the Arabian Sea. Berkeley: University of California Press.

McDow, Thomas F. 2018. Buying Time: Debt and Mobility in the Western Indian Ocean. Athens, $\mathrm{OH}$ : Ohio University Press.

McMahon, Elisabeth. 2013. Slavery and Emancipation in Islamic East Africa: From Honor to Respectability. Cambridge: Cambridge University Press.

Messick, Brinkley. 1993. The Calligraphic State: Textual Domination and History in a Muslim Society. Berkeley: University of California Press.

Miller, Joseph C. 1988. Way of Death:Merchant Capitalism and the Angolan Slave Trade, 1730-1830. Madison: University of Wisconsin Press.

Mirzai, Behnaz. 2017. A History of Slavery and Emancipation in Iran, 1800-1929. Austin: University of Texas Press.

Onley, James. 2004. "Transnational Merchant Families in the Nineteenth-Century Gulf." In Transnational Connections and the Arab Gulf, ed. Madawi Al-Rasheed. London: Routledge.

Peebles, Gustav. 2010. "The Anthropology of Credit and Debt." Annual Review of Anthropology, 39: 225-40.

Prestholdt, Jeremy. 2006. Domesticating the World: East African Consumerism and the Genealogies of Globalization. Berkeley: University of California Press. 
Prins, A.H.J. 1965. Sailing From Lamu: A Study of Maritime Culture in Islamic East Africa. Assen: Van Gorcum.

Radhi, Hassan Ali. 2003.Judiciary and Arbitration in Bahrain: A Historical and Analytical Study. London: Kluwer Law International.

Ray, Rajat Kanta. 1995. Asian Capital in the Age of European Domination: The Rise of the Bazaar, 180o-1914. Modern Asian Studies 29/3: 449-554.

Rediker, Markus. 1987. Between the Devil and the Deep Blue Sea: Merchant Seamen, Pirates and the Anglo-American Maritime World, 1700-1750. Cambridge: Cambridge University Press.

Sheriff, Abdul. 1987. Slaves, Spices, and Ivory in Zanzibar. Athens, $\mathrm{OH}$ : Ohio University Press.

Stephenson, Lindsey. 2018. "Re-Routing the Persian Gulf: The Transnationalization of Iranian Migrant Networks, c. 19oo-1940.” Unpublished Ph.D. Dissertation, Princeton University.

Thompson, E.P. 1971. The Moral Economy of the English Crowd in the Eighteenth Century. Past and Present 50: 76-136.

Udovitch, Abraham. 1970. Partnership and Profit in Medieval Islam. Princeton: Princeton University Press.

Villiers, Alan. 1969. Sons of Sinbad. New York: Charles Scribner and Sons.

Weber, Max. 1922/1978. Economy and Society: An Outline of Interpretive Sociology, 2 vols. Berkeley: University of California Press.

Wint, Hollian. 2016. "Credible Relations: Indian Finance and East African Society in the Indian Ocean, c. 1840-193o." Unpublished Ph.D. Dissertation, New York University.

Zdanowski, Jerzy. 2014. Speaking with Their Own Voices: The Stories of Slaves in the Persian Gulf in the 2oth Century. Cambridge: Cambridge Scholars Press. 